\section{Paul Nitze Responds}

To the Editors: The tone of Mr. Hudson's comment (Correspondence, Worldview, June) reflects Congressman Carr's well-known "graciousness of style." As to substance, I believe the following to be pertinent.

The particular section of Philip Morrison's article that I had in mind when I responded to Mr. Hudson's question [See "Dealing With the Soviet Union," the transcript of Mr. Nitze's presentation at a CRIA Conversation and the question and answer session that followed (Worldview, March)] reads as follows:

"From the earliest days of the ICBM's it has been recognized that a couple of hundred missiles would suffice as a second-strike deterrent, to be launched if an adversary should strike first without warning. That number can be found today in the latest reports of the Department of Defense. The U.S., however, maintains at least 9,000 -45 times 200-strategic missile warheads, and its leaders are reluctant to reduce that number."

-he language is unspecific as to how many launch vehicles would carry the 200 objects (is it missiles or is it a fortyfifth of 9,000 warheads?) referred to. In any case, I read it as being consistent with two submarine loads. The paragraph from which $\mathrm{Mr}$. Hudson prefers to quote is similarly imprecise; it leaves unspecified the number of missiles or warheads the authors would eventually desire per launch vehicle. What is clear is that they are recommending some minimum deterrent adequate only for a self-disarming, selfdefeating rovenge attack against evacuated buildings and civilians.

With respect to Mr. Daniel's letter I have little comment to offer. The questions he lists appear to me to be pertinent. There remains the problem of finding common ground on the basis of which solidly based answers can be sought. It is necessary, at a minimum, to have an agreed summary of the SALT II terms and agreed projections as to the probable U.S. and Soviet strategic deployments during the period of the SALT II treaty, assuming a continuation of the approved U.S. five-year defense program and estimated Soviet programs consistent with SALT II. At a maximum, data covering a number of important issues must be analyzed and sorted out before truly considered judgments can be arrived at.

Much of this work has been done. It keeps being obscured and made more difficult by demagogic, oversimplified, or actually misleading statements. The more important the issues the more difficult it is to impose rigor on the debate.

\section{Chinese Sources}

To the Editors: In a country as large and diverse as China all sorts of things happen. The Londons have given us some useful information about how China's food system has problems. Illegal migrants to cities lack ration books and have trouble getting food. Cadres have reported false data, which made government plans for procurement or distribution of relief supplies difficult. As China's agriculture is increasingly dependent on industrial supplies, it can be hurt by disruptions in industry and transportation. These problems have been aggravated by factional struggles associated with the succession struggle and by bad weather.

The Londons interpret these reports of problems as symptomatic of the overall situation, but this conclusion seems unwarranted. Many of the reports have emerged in Chinese political rhetoric to attack one faction. They must be used as cautiously as all other reports on China, many of which advocate policy rather than illuminate reality. The fact is that virtually no systematic surveys have been done in China, so neither the Londons, nor I, nor the Chinese Government know the precise occurrence of hunger.

The Londons are correct that macro statistics cannot capture the nuance of a concrete, specific situation. However, statistics do help interpret where on the broad distribution of reality a specific report is likely to lie. It is (continued on page 57)
The purpose of Worldview is to place public policies, particularly in international affairs, under close ethical scrutiny. The Council on Religion and International Affairs (CRIA), which sponsors the journal, was founded in 1914 by religious and civic leaders brought together by Andrew Carnegie. It was mandated to work toward ending the barbarity of war, to encourage international cooperation, and to promote justice. CRIA is independent and nonsectarian. Worldview is an im. portant part of CRIA's wide. ranging program in pursuit of these goals.

Worldview is open to diverse viewpoints and encourages dialogue and debate on issues of public significance. It is edited in the belief that large political questions cannot be considered adequately apart from ethical and religious reflection. The opinions expressed in Worldview do not necessarily reflect the positions of CRIA. Through Worldview CRIA aims to advance the national and international exchange without which our understanding will be dangerously limited.

Editorial Board

Hans Morgenthau, Chairman

William J. Barnds (on leave)

Eugene B. Borowitz

Noel J. Brown

Jorge Dominguez

James Finn

J. Bryan Hehir

Donald F. McHenry (on leave)

Paul Ramsey

Seymour Siegel

Paul Sigmund

Kenneth W. Thompson

Howard Wriggins (on leave)

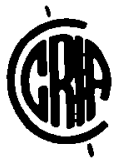

